\title{
Eldercare in Japan: Cluster Analysis of Daily Time-Use Patterns of Elder Caregivers
}

\author{
Kamila Kolpashnikova ${ }^{1}$ (D) Man-Yee $\operatorname{Kan}^{1}$
}

Received: 15 March 2020 / Accepted: 5 November 2020 / Published online: 20 November 2020

(C) The Author(s) 2020

\begin{abstract}
Using the data of the 2006 Japanese Survey on Time Use and Leisure Activities, we perform cluster analysis and identify seven unique patterns of daily time-use patterns of co-resident family elder caregivers: (1) 'Overworkers', (2) 'Full-time Workers', (3) 'Part-time Workers', (4) 'Intensive Caregivers', (5) 'Houseworkers', (6) 'Leisurely', and (7) caregivers, who needed medical attention on the diary day ('Emergency Diaries'). Our results show that the 'Houseworkers' and 'Intensive Caregivers' spend the most time on adult caregiving activities. Care activities for 'Houseworkers' are more likely to coincide with longer housework hours, increasing the total unpaid work volume. The analysis of demographic profiles suggests that similar daily patterns on weekdays and weekends do not belong to people with the same demographic characteristics. For instance, although on weekdays, 'Leisurely Caregivers' are mostly represented by the elderly taking care of other elderly, people of any age can belong to this category on weekends. Among all types of caregivers, only 'Intensive Caregivers' are as likely to be men as they can be women, suggesting that when the need for eldercare increases, family caregivers of any gender will step in.
\end{abstract}

Keywords Eldercare · Japanese elder caregivers · Long-term care system · Sequence analysis

\section{Introduction}

Although elder caregivers may enjoy the emotional rewards of taking care of elderly parents and spouses (Folbre 2012; Silverstein and Giarrusso 2010), they hardly receive

Kamila Kolpashnikova

kamila.kolpashnikova@sociology.ox.ac.uk

Man-Yee Kan

man-yee.kan@sociology.ox.ac.uk

1 Department of Sociology, University of Oxford, Oxford, UK 
any economic benefits (Bianchi et al. 2006; Wolf and Soldo 1994; Zuba and Schneider 2013). When caregiving is assumed to be the responsibility of specific groups more than others, these groups may accumulate substantial disadvantages. Moreover, negative consequences for well-being are reported for caregivers, who accumulate a greater share of the disadvantages which come together with care provision, such as having to quit paid work or having to take up part-time and low-paid jobs (Bookman and Kimbrel 2011; Freedman et al. 2019).

There are two main contributions of the present paper. The first is that we add to a very limited collection of studies on the time-use patterns and everyday routines of elder caregivers (Freedman et al. 2019), pushing forward the understanding of how the daily time-use patterns can be analyzed for particular segments of the population. Many studies used sequence and cluster analyses to describe time-use patterns of the elderly, but not of caregivers (Grapsa and Posel 2016; Schulz and Eden 2016). Using American time-use data, Freedman et al. (2019) produced a seminal work and trailblazed the analysis of the daily patterns of family caregivers.

However, there are a few points that need to be raised with respect to the analysis in Freedman et al. (2019). First, they do not differentiate between different types of noncare activities, thus excluding important aspects shaping daily patterns. Flood et al. (2018) demonstrate that, in general, everyday life is organized around the following big types of daily activities: (1) childcare and housework, (2) leisure, and (3) paid work. Although Freedman et al. (2019) disaggregate the first aspect (except childcare), they conflate the other two. As a result, the main routine organizing aspects such as paid work and leisure, emphasized in Flood et al. (2018), are not differentiated in the analysis.

Second, Freedman et al. (2019) assign a higher substitution cost to transitions between care activities and non-care activities compared to the cost of transitions within care-activities. This was done to emphasize caregiving versus all non-care activities (including paid work, leisure, and childcare). However, as their analysis shows, this approach results in clusters forming based on caregiving intensity. This is a direct result of a higher substitution cost for all non-care activities. Therefore, with minor exceptions, such an analysis is hardly distinguishable from that, which could be achieved by categorizing caregivers based on the aggregate time they spend providing care.

Third, most research focuses on the analysis of weekday time-use patterns, disregarding weekends, including Freedman et al. (2019), Glorieux et al. (2010), and Flood et al. (2018). Although such analyses provide theoretical and empirical parsimony, they do not consider the fact that even if the patterns of activities appear the same on weekdays and weekends, they might not belong to the same demographics. For instance, people working full-time on weekdays are very likely not to be of the same demographics as those who work full-time on weekends because working on weekends suggests employment in a contingent work rather than regular employment on weekdays. Similarly, the people who spend their days on leisure activities during weekdays are not similar to those who spend their weekends on leisure activities. While the latter might be anyone with regular employment, the former is likely to be someone not in the active labor force, particularly those who are retired.

Our study has implemented the ideas above, focusing on the time-use patterns of elder caregivers. It has taken into consideration findings in Flood et al. (2018) and 
Glorieux et al. (2010) to extend what was started in Freedman et al. (2019). This paper will also be the first study to investigate caring work in a super-ageing society. We chose Japan, which is the country with one of the highest proportions of the aging population and arguably one of the best social support systems in eldercare (HelpAge International 2014). Moreover, the Japanese time-use data provides us with a large sample of self-reported caregivers (for comparison, Freedman et al. (2019) had only 351 caregivers in their sample, whereas our study analyzes diaries of 3496 caregivers). Choosing self-reported caregivers, while analyzing daily caregiving activities as well, helps identify the types of caregivers that tend to overestimate or underestimate their caregiving involvement.

Taking the above considerations in mind, the main objectives of the present paper, therefore, are to investigate: (1) the types of caregivers based on their daily time-use patterns; (2) the demographic profiles of caregivers, including their employment status, socioeconomic status, gender, and age.

\section{Contextual Background: Eldercare in Japan and the Long-Term Care Insurance System}

The elderly in Japan benefit from a better support system from the government than in the US or the UK, such as universal healthcare and long-term care insurance (LTCI) system for those above 65 , introduced in 2000 . The LTCI was initiated to alleviate the burden of women-caregivers and ensure safe and dignified aging for Japan's elderly (Tamiya and Shikata 2010). The benefits offered by the program of LTCI can be accessed through care professionals to acquire institutional care or community-based help. ${ }^{1}$

Initially, the program proved to be effective in decreasing the care burden on women (Tamiya and Shikata 2010). However, due to the rapid increase in the elderly population, the Japanese government faced financial strains in implementing the system because the number of users of LTCI doubled since the beginning of the program from 1.2 million in 2000 to 2.6 million people in 2007 (Tamiya and Shikata 2010). The government took steps to share eldercare obligations back with local communities and the families of the elderly. This course of governmental policy was driven by the precipitous increase in the elderly population in Japan. The elderly represented about $20 \%$ of the population in 2005, and the number rose to $27 \%$ in 2015 . Moreover, they are projected to reach almost $40 \%$ of the population in 2050 (Ato and Tsuya 2018).

Even though Japan has a progressive system of local and federal support for the elderly, most eldercare in Japan remains the burden of family members. Morikawa (2018) argues that the policy implementation could not reach the universal level partly due to an unexpectedly high level of financial strain on the country's budget and the prevalence of traditional norms for taking care of the elderly (Yajima 2017). Because of the unanticipated spurt of eldercare demand, when the number of enrolments doubled within the first five years since the implementation of the long-term care system in 2000 , the government found itself forced to revise the policy from its initial focus on

\footnotetext{
${ }^{1}$ See Inamori (2017) for comprehensive review of the LTCI.
} 
the public provision ('shakaika') back to local ('chiikika'), and de facto family provision ('zaikazokuka').

The changes in the 2000 LTCI law that were introduced in 2005, therefore, stymied the increase in enrolment as well as the number of eligible claimants to a more comprehensive care. The process nowadays involves going through local committee vetting to determine the level of need. Ninety percent of the care cost was covered under the 2005 changes, and families covered $10 \%$. There are also ceiling costs (upper limits), above which families must pay for eldercare themselves. Because the LTCI does not meet all the needs for eldercare at the moment (Inamori 2017), a substantial amount of eldercare is provided by those who co-reside with the elderly, i.e. their family members.

Two years after the 2005 revision, $60 \%$ of the elderly co-resided with family members. Thus, co-residing family care comprised $66.1 \%$ of all caregivers in 2004; the figure slowly declined to $61.6 \%$ in 2013 (Morikawa 2018). The change was mostly attributed to the decrease in caregiving from in-laws and a commensurate increase in the use of paid care facilities (Morikawa 2018). The number remains high for family caregiving not only because the LTCI cannot provide institutional help to everyone who needs it, but also because there are strong traditional norms for family members to care for their elderly (Yajima 2017). Research also shows that the decrease of caregiving happened mostly in the younger cohorts, rather than the older ones (Kikuzawa 2007).

Among family eldercare recipients, $25 \%$ of all were taken care of by their spouses, $17.9 \%$ - by their children, and $14.3 \%$ - by spouses of their children (Morikawa 2018). Although the proportions of family care recipients decreased, while the proportions of institutional care recipients increased, in the first five years of the LTCI system implementation, the trend stalled on the same level since 2007, as reported above. The biggest increase in the institutional provision from $9.3 \%$ to $13.6 \%$ was registered in 2001 and 2004 (Morikawa 2018). Both years were after the initial implementation of LTCI in 2000. However, the level of institutional provision did not change considerably from 2004 to 2013 . It was $13.6 \%$ in 2004 and $14.8 \%$ in 2013 , making it a mere $1.2 \%$ increase.

The original purpose of the long-term care insurance system was to move from the family caregivers' model to a public system. Ideally, such a system should have alleviated the burden on families, particularly on women. However, Morikawa (2018) insists that these ideals were revised, facing harsh realities of budgetary constraints. She argues that the burden on children and spouse caregivers continues to remain unaffected by the long-term care system, and other scholars agree (Inamori 2017). Inamori (2017) reports that, together with increased enrolment, the insurance premium rose as well. In the first two years since implementation, they were around 2911 yen but rose up to 5514 yen in the 2015-2019 fiscal years.

\section{Common Characteristics of Caregivers}

Although there is extensive qualitative research of the life of caregivers (Aoun et al. 2015; Tay et al. 2016; Weisser et al. 2015) and their physical and mental health (Boltz et al. 2015; Hou et al. 2014), little is known in quantitative research about how the timeuse patterns of caregivers look like, and whether there are commonalities in what they 
do on regular days (i.e., whether we can identify specific categories of caregivers). The only exception is the most recent study by Freedman et al. (2019).

For elder caregivers, the hours of paid work are important for organizing daily activities. Flood et al. (2018) show that paid work time forms particularly distinct arrangements of time depending on the work schedules, including standard and nonstandard work. The importance of work time in the analysis of other activities was also emphasized in Glorieux et al. (2010) in their analysis of leisure time. With respect to caregiving in Japan, Ikeda (2017) shows that only if women and men work less than $7 \mathrm{~h}$ a day, they are likely to keep their jobs, whereas if the caregiver works 8 or more hours (this includes full-time job), then it becomes unlikely for the caregiver to keep continuous employment, even when the Family Care Leave provisions are taken into account. $^{2}$

Tsudome (2018) argues that caregiving nowadays always occurs together with other activities (nagara caregiving — caregiving 'while' doing something). He particularly emphasizes the caregiving 'while' working, arguing that nowadays, more than half of caregivers have to work. In the 2016/2017 fiscal year, 99100 people had to quit their jobs to take care of their family members. Among them, 24600 were men (most were single men) (Tsudome 2018). Although the number of women who had to quit their jobs decreased compared to five years before, the number of men increased by almost 6000 people (Tsudome 2018). The trend is likely to continue in the future.

For those caregivers who can still afford to work, it is reasonable to expect some weekday and weekend differences in partaken activities. The patterns of most weekend activities are unlike those on weekdays (Hook 2017; Ruppanner and Treas 2015; Kolpashnikova and Kan 2020). For instance, Ruppanner and Treas (2015) showed that employment on the weekend benefited men in terms of reducing their housework and care activities but did not alleviate women's unpaid work. Furthermore, Hook (2017) found that women are more likely to engage in gender-asserting activities on weekends, such as participating in more traditionally feminine activities like housework and care activities. Kolpashnikova and Kan (2020) showed that women were more likely to postpone unpaid work to weekends if they had work responsibilities during the week. All these studies on differences between weekday and weekend activities suggest that the daily patterns of caregivers might differ by weekday, too.

Employment of women and men co-residing with parents may also depend on the intensity of the required eldercare. Ikeda (2017) reports that women co-residing with healthier parents under 75 are more likely to afford to work. However, when the amount of care that parents require increases, the trend reverses. Women can no longer hold a job and take care of the elderly at the same time (Ikeda 2017). There is no reason to think that the same would not apply to men, as well, particularly to single men. Thus, co-residence with an elderly by itself might not be a factor in terms of defining whether a woman would continue to be employed or quit her job. It is the amount of the required eldercare that becomes a defining factor.

Thus, on the one hand, co-residing with grandparents alleviates childcare burden, especially when co-residing grandparents are younger and healthier (Tamiya and Shikata 2010; Ikeda 2017). On the other hand, there are studies (Fukuda 2018) arguing that among Japanese sandwich caregivers (those who have to provide both eldercare

\footnotetext{
${ }^{2}$ For more detailed review of the Family Care Leave legislation, please see Inamori (2017).
} 
and childcare), the proportion of eldercare rose concurrently with childcare, particularly in the households where the elderly needed care themselves. For caregivers, therefore, these two care activities were not in a time-constraint/role-conflict relationship but actually increased in tandem. A simultaneous increase in eldercare and childcare may lead to drastic changes in work schedules, reduction of paid work time, or exit from the workforce, among other things (Bianchi et al. 2006; Wolf and Soldo 1994; Zuba and Schneider 2013).

This distinct category of sandwich caregivers has been given much attention in the literature (Henretta et al. 2001; Suh 2016; Yamashita and Soma 2015). Although overall proportions of the three-generation families are decreasing-from $25.2 \%$ in 1986 to $12.3 \%$ in 2006 (Tamiya and Shikata 2010) - it is usually assumed to be women in their 30s and 40s who have elderly parents and young children to take care of at the same time. Another growing population, which is not discussed as much in this regard, is the elderly sandwich caregivers - partners of women and men who need intensive eldercare and who also provide childcare for their grandchildren to support the working schedules of their employed children.

As to men caregivers, the social expectations of filial care often do not discriminate by gender in western societies (Henz 2010; Szinovacz and Davey 2008). Nevertheless, recent studies show that gender equity in providing eldercare between spouses actually does not hold up at the aggregate (societal) level. The mechanism resulting in such paradox lies in the division of eldercare between siblings (Grigoryeva 2017). More often than not, the outcome is gendered - sisters are more likely to take care of their parents than brothers. This means that there are gender differences in eldercare on the aggregate level due to the sibling differentials. Overall, other studies showed that women, married and single alike, take on more care work than men (Bianchi et al. 2000; Moen et al. 1994; Nichols and Junk 1997). Yet, with decreasing numbers of children per married couple, it is likely that the gender gap among sibling caregivers will continue to decline.

There is also abundant literature on men-caregivers in Japan (Tsudome 2018; Hiroyama 2017). Most men-caregivers are, however, spouses of the elderly women and sons of the elderly parents. One out of three caregivers is now said to be either husband- or son-caregivers to the elderly partners or parents (Tsudome 2018). Hiroyama (2017) reports that the number of husbandcaregivers increased from $11.6 \%$ in 2001 to $13.9 \%$ in 2013 , whereas the number of son-caregivers increased from $10.7 \%$ in 2001 to $16.3 \%$ in 2013. He points out that the increase in the numbers of son-caregivers was particularly preeminent among single men. Considering the trends in delayed marriage and the decrease in the overall marriage rates, the proportions of son-caregivers are bound to increase unfettered.

Although their wives usually take up most caregiving responsibilities for married men in Japan, the amount of caregiving that men perform is increasing. The exceptions are for those men who are working long hours and have other co-resident family members, often women, who can take care of the elderly in their stead (Nishimoto 2017). Particularly, the norms of long working hours, on par with strong traditional gender expectations (Saito 2017), are at the core why many married men cannot contribute more to the unpaid work at home (Yajima 2017). 


\section{Methods}

\section{Data and Sample}

This paper uses anonymized microfiles of the 2006 Survey on Time Use and Leisure Activities Questionnaire A (STULA) (Statistics Bureau 2016). STULA collects time diaries for two consecutive days from a representative sample of the Japanese population. The survey sample uses a two-stage stratified sampling method. STULA does not collect secondary activities. The initial microfile data contained 272861 observations. The first step we took for the present study, we restricted the sample to the first diary day only. Because the STULA collects the data for two consecutive days, we believe that the second-day reporting can be contaminated with the reports or inaccurate reports due to filling in the STULA questionnaire on the diary day. The total sample for the comparison in the present study employed 136596 observations of at-home family caregivers and non-caregivers on their first diary day. In the analysis of sequences for the caregivers, we limited the sample to those who self-reported that they provide eldercare at home (3555 raw observations, $2.6 \%$ of the respondents on the first diary day).

The original question used for the definition of caregivers was the following: "Do you usually provide adult care to family members? To members of 65 and above years of age at home?" ${ }^{3}$ Those who responded positively that they provided adult care to family members of 65 and over were coded as caregivers. The sample includes those who provide horizontal care (care to spouses and siblings), which is shown to be important and needs to be included in the measurement of caregiving in the caregiving literature (Patterson and Margolis 2019). In 2006 STULA, co-residing caregivers comprised $64.11 \%$ of all elder caregivers (3555 out of 5545 observations). Out of $3555,3496(98.3 \%)$ observations had no missing values for the main independent variables used for constructing the demographic profiles in this study.

The weighted sample of complete observations (2960.908) consists of 2134.074 observations on weekdays and 826.834 observations on weekends. The raw observations on weekends (2169) are more than twice more than the weighted sample because STULA oversampled on weekends. Weights correct for the weekend oversampling. We restricted the sample to those who provide eldercare at home to focus on family caregiving.

Although 2006 STULA is an old data, the trends among caregivers, who take care of their own parents, have been shown to have remained on a similar level since 2005 and remained on a similar level through 2013 (Morikawa 2018). Therefore, we expect to see the patterns established in the 2006 STULA in the later years as well and conclude that the 2006 data might be representative of the post-revision era of the long-term care system, although, of course, with great caution.

The restricted sample of the caregivers on the first diary day allowed us to preserve the computational speed as well as the visibility of results (when plotted together, a larger number of sequences tend to blur). However, we ran the robustness check for the clustering for the second day as well. The results for the second diary day were similar to those reported here.

3『ふだん家族の介護をしていますか. 介護:65歳以上の家族を介護(自宅内)』 
We added the variable Employed, which is a dummy variable ( $0=$ 'not employed', $1=$ 'employed'). Income is the variable measuring the quartiles of household income. Initially, age was categorized in 4 groups: under 20, 20-34, 35-64, and 65+. We created variables for children: whether the youngest child was of (1) 0-4 (2) 5-14, and (3) 15-19 years of age. We chose 19 because, in Japan, the age of adulthood is 20. We also added the variables measuring the number of adult women in the household and the household size.

In the process, we realized that respondents' age could not be used categorically because some of the clusters form around certain ages and do not contain any observations of certain age categories (same occurred with the age categories of youngest children). We could, however, create two categories for respondents' age: below 65 and above, to identify clusters with caregivers, who are elderly themselves. Additionally, the average age of children could not work because it becomes impossible to distinguish those with children under 1 and those who do not have children (both would be coded as zeroes).

The possible categorization was between those who do not have children (which also include children of 15 and above) and those who have children between 0 and 14, and because it was better to use the number of children in this case, so eventually, we opted to use the number of children under 15. Because of the identification problem of the variables on the number of household members, we left only the number of children under 15 and the number of adult women.

\section{Sequence Analysis}

We use the TraMiner R package (Gabadinho et al. 2011; Studer and Ritschard 2016) to investigate the time-use patterns and characteristics of caregivers in Japan. We ordered reported activities throughout the day into sequences; each step represented a 15-min interval, totaling 96 steps. The initial number of activities (20) was reduced to 7: (1) sleep and self-time, (2) travel and commute, (3) work and study, (4) housework, (5) adult care, (6) childcare, and (7) leisure and eating. The information on initial activities and how they were coded into the resulting activities are available upon request.

It is important to note that the activities for adult care (predominantly eldercare for the sample) are also often used as a measure for identifying family caregivers. However, care activities, both eldercare and childcare, often coincide with other unpaid work, particularly housework. Thus, when housework is done to take care of the elderly in the household, it is not coded as eldercare. Moreover, STULA underestimates the childcare because the care for children above 6 is coded as housework, rather than childcare.

Bittman et al. (2005) show that time-use diaries underestimate the care time precisely for the reason that it often coincides with housework. Therefore, a lot of eldercare and childcare might go untracked. Choosing self-identified caregivers helps to reduce this underestimation. We combined many categories of leisure into the same category because the substitution between the leisure activities would not be meaningful for the analysis of eldercare.

Each sequence is then compared to other sequences using the optimal matching technique (the Needleman-Wunsch algorithm) (Abbott 1995; Abbott and Tsay 2000; Sankoff and Kruskal 1983). The substitution cost, defined as the cost of substituting 
one state with another, was calculated from the estimated transition states, which were all close to 2 (the default). As we argued in the introduction, emphasizing caregiving activities over non-caregiving activities as in Freedman et al. (2019) will result in bigger distances between sequences of different caregiving time lengths. Thus, later the clustering will identify categories based on caregiving time, which makes it indistinguishable methodologically from creating initial categories based on the length of caregiving and avoiding the sequence analysis altogether.

Another cost that needs to be set up for dissimilarity calculations is the indel cost, defined as the cost of inserting or deleting an element in a sequence. Considering the number of sequence steps, we kept the indel cost at 1 (the default), which is also different from Freedman et al. (2019), who further decreased the indel cost to 0.5. However, considering a large number of sequences (96), while the timings of activities, such as work schedules, usually shift in increments of an hour, we decided to keep the default indel cost because substitutions cost usually should not be more than twice as higher than the indel cost. Since substitution is one deletion and one insertion, if the substitution cost is higher than the cost of two indels, this logic is broken. Therefore, we considered both the variety of activity transitions and the timings of the activities in the clustering. Based on the dissimilarity matrix obtained from the optimal matching, we performed the cluster analysis. We clustered the activity sequences into seven main groups for the weekdays' sample and six main groups for the weekend sample, based on the main branches of the resulting clustering dendrograms and cluster validity analysis. The results of this procedure are available upon request.

In addition, to analyze which demographic characteristics are associated with being clustered into a specific group of caregivers, we performed multinomial logistic regression against demographic factors for weekday and weekend samples separately. We report the average marginal effects in Tables 5 and 6.

\section{Results and Discussions}

\section{Cluster Analysis Results}

We employed cluster analysis on the sequences of self-reported caregivers and identified seven main clusters using the weekday sample and six clusters using the weekend sample. These clusters or categories of sequences represent different types of daily activity patterns among Japanese family caregivers. Tables 1 and 2 summarize the averages for main activities for different caregivers' clusters on weekdays and weekends, respectively. It is worth noting that non-caregivers, presented in Tables 1 and 2 for comparison, spend substantially less time on adult care- 2 min versus almost $50 \mathrm{~min}$ a day on average for family caregivers.

Based on the mean estimates for certain activities, we can identify which activities are prevalent in each cluster. For instance, Group 5 on weekdays and Group 6 on weekends show the highest average for the time spent on adult care (574 and $315 \mathrm{~min}$, respectively). Therefore, we named them the 'Intensive Carers'.

The average amount of paid work for three groups out of seven on weekdays and two groups out of six on weekends is substantially higher than in other groups, particularly for Group 6 on weekdays. We can call all these groups collectively 
Table 1 Mean (SD) of Main Activities on Weekdays

\begin{tabular}{|c|c|c|c|c|c|c|c|}
\hline & Sleep & Leisure & Travel & Work & Housework & Adult care & Childcare \\
\hline Group 1 (Houseworkers) & $\begin{array}{l}550.348 \\
(117.385)\end{array}$ & $\begin{array}{l}442.079 \\
(136.309)\end{array}$ & $\begin{array}{l}26.933 \\
(43.688)\end{array}$ & $\begin{array}{l}6.404 \\
(26.491)\end{array}$ & $\begin{array}{l}331.180 \\
(141.069)\end{array}$ & $\begin{array}{l}70.719 \\
(88.234)\end{array}$ & $\begin{array}{l}12.337 \\
(58.020)\end{array}$ \\
\hline Group 2 (Part-time Workers) & $\begin{array}{l}514.961 \\
(93.542)\end{array}$ & $\begin{array}{l}399.213 \\
(135.792)\end{array}$ & $\begin{array}{l}54.803 \\
(60.426)\end{array}$ & $\begin{array}{l}280.630 \\
(107.871)\end{array}$ & $\begin{array}{l}143.976 \\
(126.579)\end{array}$ & $\begin{array}{l}41.457 \\
(83.740)\end{array}$ & $\begin{array}{l}4.961 \\
(38.269)\end{array}$ \\
\hline Group 3 (Leisurely) & $\begin{array}{l}570.184 \\
(104.310)\end{array}$ & $\begin{array}{l}729.202 \\
(113.374)\end{array}$ & $\begin{array}{l}13.344 \\
(33.458)\end{array}$ & $\begin{array}{l}6.902 \\
(36.902)\end{array}$ & $\begin{array}{l}87.883 \\
(91.285)\end{array}$ & $\begin{array}{l}31.656 \\
(67.557)\end{array}$ & $\begin{array}{l}0.828 \\
(7.862)\end{array}$ \\
\hline $\begin{array}{l}\text { Group } 4 \text { (Full-Time } \\
\quad \text { Workers) }\end{array}$ & $\begin{array}{l}513.090 \\
(82.856)\end{array}$ & $\begin{array}{l}281.344 \\
(90.375)\end{array}$ & $\begin{array}{l}50.389 \\
(55.011)\end{array}$ & $\begin{array}{l}476.193 \\
(89.708)\end{array}$ & $\begin{array}{l}99.611 \\
(113.564)\end{array}$ & $\begin{array}{l}16.809 \\
(38.785)\end{array}$ & $\begin{array}{l}2.563 \\
(16.806)\end{array}$ \\
\hline Group 5 (Intensive) & $\begin{array}{l}520.962 \\
(113.093)\end{array}$ & $\begin{array}{l}216.923 \\
(120.541)\end{array}$ & $\begin{array}{l}4.038 \\
(15.622)\end{array}$ & $\begin{array}{l}0.000 \\
(0.000)\end{array}$ & $\begin{array}{l}124.038 \\
(144.596)\end{array}$ & $\begin{array}{l}574.038 \\
(142.338)\end{array}$ & $\begin{array}{l}0.000 \\
(0.000)\end{array}$ \\
\hline Group 6 (Overworkers) & $\begin{array}{l}459.590 \\
(73.537)\end{array}$ & $\begin{array}{l}214.180 \\
(99.279)\end{array}$ & $\begin{array}{l}53.852 \\
(52.024)\end{array}$ & $\begin{array}{l}675.861 \\
(101.923)\end{array}$ & $\begin{array}{l}28.156 \\
(60.173)\end{array}$ & $\begin{array}{l}6.762 \\
(23.230)\end{array}$ & $\begin{array}{l}1.598 \\
(9.605)\end{array}$ \\
\hline Group 7 (Emergency) & $\begin{array}{l}839.348 \\
(195.191)\end{array}$ & $\begin{array}{l}376.304 \\
(137.870)\end{array}$ & $\begin{array}{l}127.500 \\
(176.458)\end{array}$ & $\begin{array}{l}15.652 \\
(51.182)\end{array}$ & $\begin{array}{l}44.674 \\
(73.586)\end{array}$ & $\begin{array}{l}36.522 \\
(63.926)\end{array}$ & $\begin{array}{l}0.000 \\
(0.000)\end{array}$ \\
\hline Total & $\begin{array}{l}539.322 \\
(122.446)\end{array}$ & $\begin{array}{l}397.393 \\
(189.200)\end{array}$ & $\begin{array}{l}40.479 \\
(61.997)\end{array}$ & $\begin{array}{l}235.354 \\
(259.192)\end{array}$ & $\begin{array}{l}172.076 \\
(165.850)\end{array}$ & $\begin{array}{l}49.748 \\
(104.580)\end{array}$ & $\begin{array}{l}5.629 \\
(37.295)\end{array}$ \\
\hline Non-Caregivers & $\begin{array}{l}540.887 \\
(129.143)\end{array}$ & $\begin{array}{l}408.853 \\
(205.259)\end{array}$ & $\begin{array}{l}57.633 \\
(70.703)\end{array}$ & $\begin{array}{l}308.625 \\
(267.054)\end{array}$ & $\begin{array}{l}109.603 \\
(152.155)\end{array}$ & $\begin{array}{l}2.426 \\
(26.989)\end{array}$ & $\begin{array}{l}11.973 \\
(59.195)\end{array}$ \\
\hline$N$ & 1327 & 1327 & 1327 & 1327 & 1327 & 1327 & 1327 \\
\hline$W t N$ & 2134.074 & 2134.074 & 2134.074 & 2134.074 & 2134.074 & 2134.074 & 2134.074 \\
\hline
\end{tabular}

'Workers'. Among them, Group 6 caregivers report more than $11 \mathrm{~h}$ of paid work on an average weekday. Due to the longest working hours, they can be referred to as 'Overworkers', while Group 4 on weekdays and Group 2 on weekends can be referred to as 'Full-time Workers' because the hours for this category are close to those of fulltime employment ( $8 \mathrm{~h}$ a day). Considering that both groups of 'Full-time Workers' report considerable time spent on housework, these groups may also include the second shifters, discussed in the theoretical part. Group 2 on weekdays and Group 1 on weekends can be referred to as 'Part-time Workers' because their time spent on work is closer to part-time employment hours. We also note that 'Full-time Workers' spend more time on total work (work + housework + adult care + childcare) than 'Part-time Workers'.

Group 1 on weekdays and Groups 4 and 5 on weekends do the highest amount of housework and very little paid work ( 5 to $6 \mathrm{~min}$ a day). We refer to them as 'Houseworkers' category. On weekends, Group 4 reports a longer time, on average, spent on childcare than Group 5. Thus, Group 1 on weekdays (also a cluster with higher childcare time) and Group 4 on weekends may also include the sandwich caregivers discussed in the literature review.

Groups 3 on weekdays and weekends report the longest hours of leisure time. Therefore, we refer to them as 'Leisurely Carers'. The other group that stands alone (similar to 'Overworkers') is Group 7 on weekdays. They report long sleeping hours 
Table 2 Mean (SD) of Main Activities on Weekends

\begin{tabular}{|c|c|c|c|c|c|c|c|}
\hline & Sleep & Leisure & Travel & Work & work & $\begin{array}{l}\text { Adult } \\
\text { care }\end{array}$ & ildcare \\
\hline $\begin{array}{l}\text { Group } 1 \text { (Part-Time } \\
\text { Workers) }\end{array}$ & $\begin{array}{c}540.948 \\
(108.747)\end{array}$ & $\begin{array}{c}415.428 \\
(150.254)\end{array}$ & $\begin{array}{c}40.706 \\
(59.754)\end{array}$ & $\begin{array}{c}270.056 \\
(101.243)\end{array}$ & $\begin{array}{c}143.922 \\
(137.596)\end{array}$ & $\begin{array}{c}25.874 \\
(51.845)\end{array}$ & $\begin{array}{c}3.067 \\
(19.083)\end{array}$ \\
\hline $\begin{array}{l}\text { Group } 2 \text { (Full-Time } \\
\text { Workers) }\end{array}$ & $\begin{array}{l}507.087 \\
(90.093)\end{array}$ & $\begin{array}{c}282.888 \\
(105.289)\end{array}$ & $\begin{array}{c}44.891 \\
(51.618)\end{array}$ & $\begin{array}{c}524.672 \\
(115.785)\end{array}$ & $\begin{array}{c}68.046 \\
(90.771)\end{array}$ & $\begin{array}{c}9.903 \\
(31.150)\end{array}$ & $\begin{array}{c}2.512 \\
(18.797)\end{array}$ \\
\hline (Leisurely) & $\begin{array}{c}583.937 \\
(126.432)\end{array}$ & $\begin{array}{c}726.102 \\
(159.697)\end{array}$ & $\begin{array}{c}64.567 \\
(121.663)\end{array}$ & $\begin{array}{c}5.000 \\
(21.500)\end{array}$ & $\begin{array}{c}41.732 \\
(64.806)\end{array}$ & $\begin{array}{c}17.913 \\
(46.601)\end{array}$ & $\begin{array}{c}0.748 \\
(8.842)\end{array}$ \\
\hline Group 4 (Houseworkers 1) & $\begin{array}{c}555.587 \\
(108.918)\end{array}$ & $\begin{array}{c}533.584 \\
(140.428)\end{array}$ & $\begin{array}{c}32.282 \\
(54.560)\end{array}$ & $\begin{array}{c}6.032 \\
(32.171)\end{array}$ & $\begin{array}{c}255.633 \\
(109.040)\end{array}$ & $\begin{array}{c}38.539 \\
(60.042)\end{array}$ & $\begin{array}{c}18.343 \\
(75.221)\end{array}$ \\
\hline Group 5 (Houseworkers 2) & $\begin{array}{l}507.748 \\
(89.300)\end{array}$ & $\begin{array}{c}346.773 \\
(108.900)\end{array}$ & $\begin{array}{c}13.994 \\
(27.980)\end{array}$ & $\begin{array}{c}5.080 \\
(26.423)\end{array}$ & $\begin{array}{c}469.073 \\
(120.886)\end{array}$ & $\begin{array}{c}90.192 \\
(106.825)\end{array}$ & $\begin{array}{c}7.141 \\
(37.959)\end{array}$ \\
\hline Group 6 (Intensive) & $\begin{array}{c}665.423 \\
(246.864)\end{array}$ & $\begin{array}{c}302.538 \\
(129.590)\end{array}$ & $\begin{array}{c}21.577 \\
(49.309)\end{array}$ & $\begin{array}{c}20.192 \\
(69.149)\end{array}$ & $\begin{array}{c}114.692 \\
(104.790)\end{array}$ & $\begin{array}{c}314.538 \\
(221.558)\end{array}$ & $\begin{array}{c}1.038 \\
(8.392)\end{array}$ \\
\hline Total & $\begin{array}{c}549.219 \\
(125.826)\end{array}$ & $\begin{array}{c}464.322 \\
(204.275)\end{array}$ & $\begin{array}{c}38.112 \\
(70.370)\end{array}$ & $\begin{array}{c}137.822 \\
(216.781)\end{array}$ & $\begin{array}{c}190.927 \\
(175.746)\end{array}$ & $\begin{array}{c}51.902 \\
(107.644)\end{array}$ & $\begin{array}{c}7.697 \\
(46.058)\end{array}$ \\
\hline Non-Caregivers & $\begin{array}{c}567.514 \\
(138.082)\end{array}$ & $\begin{array}{c}516.377 \\
(226.726)\end{array}$ & $\begin{array}{c}54.145 \\
(81.834)\end{array}$ & $\begin{array}{c}161.834 \\
(239.404)\end{array}$ & $\begin{array}{c}124.819 \\
(155.917)\end{array}$ & $\begin{array}{c}2.176 \\
(25.186)\end{array}$ & $\begin{array}{c}13.134 \\
(62.360)\end{array}$ \\
\hline$N$ & 2169 & 2169 & 2169 & 2169 & 2169 & 2169 & 2169 \\
\hline$W t N$ & 826.834 & 826.834 & 826.834 & 826.834 & 826.834 & 826.834 & 826.834 \\
\hline
\end{tabular}

and personal care time (including medical care). After confirming their diaries' details, we can report that these diaries belong to people who needed medical attention during the diary day. We decided to refer to these as the 'Emergency Diaries'.

In order to visualize the daily patterns of caregivers, Figs. 1 and 2 summarize the tempograms (sequence density plots) for different groups of clusters on weekdays and weekends. In all tempograms, each step within sequences represents a 15-min interval, totaling 96 such intervals in a 24-h day. Each sequence starts at 00:00 am and ends at 11:59 pm. The $\mathrm{x}$-axis in all sequence density plots (tempograms) represents the hours and minutes of the diary day from 12 am to $11: 59 \mathrm{pm}$.

The leftmost panels in Fig. 1 represent 'Full-time Workers'. The tempograms show that they work during the day and do some housework with adult and childcare in the mornings and evenings (or during what can be called their 'second shift'). The panels in the middle of Fig. 1 represent the daily patterns of 'Part-time Workers'. Their tempograms show that generally speaking, some proportions of 'Part-time Workers' work the morning shifts and some work afternoon shifts. The hours of housework and care work for 'Part-time Workers' stretches over the entire day. Finally, the rightmost panels show the daily patterns of 'Intensive Carers'. These tempograms reveal that most of the day for this type of caregivers is taken up by adult care.

In Fig. 2, the top leftmost and rightmost tempograms show the unique categories of 'Overworkers' (leftmost) and those who needed medical attention 'Emergency Diaries' (rightmost). For 'Overworkers', the entire day, including evenings, is devoted to working activities. In 'Emergency Diaries', most of the day is spent on sleep and 
$\square$ Sleep and Personal $\square$ Travel $\square$ Work/Study $\square$ Housework $\square$ Adult Care $\square$ Child Care $\square$ Leisure and Eating

\section{Weekday}
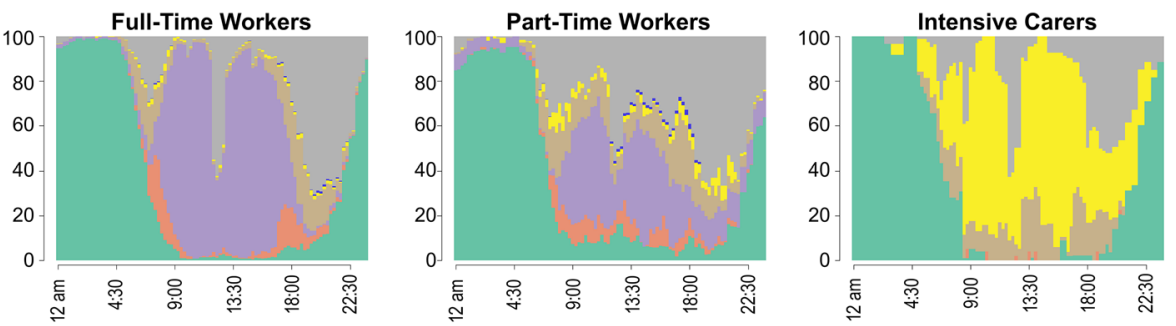

\section{Weekend}
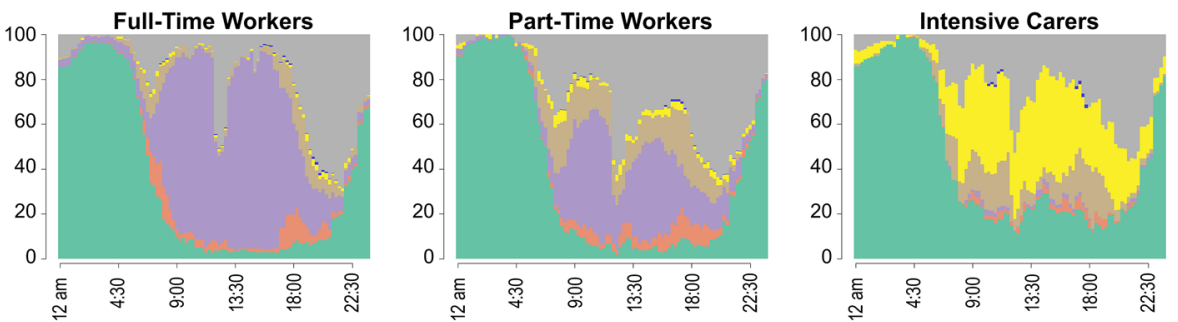

Fig. 1 Daily Patterns on Weekdays and Weekends

personal medical services. We also note that there is a considerable amount of travel and some adult care reported throughout the day in these diaries.

In the middle, the tempograms represent the daily patterns of 'Houseworkers' on weekdays and weekends. They summarize that most of the day for this category is

$\square$ Sleep and Personal $\square$ Travel $\square$ Work/Study $\square$ Housework $\square$ Adult Care $\square$ Child Care $\square$ Leisure and Eating

Weekday
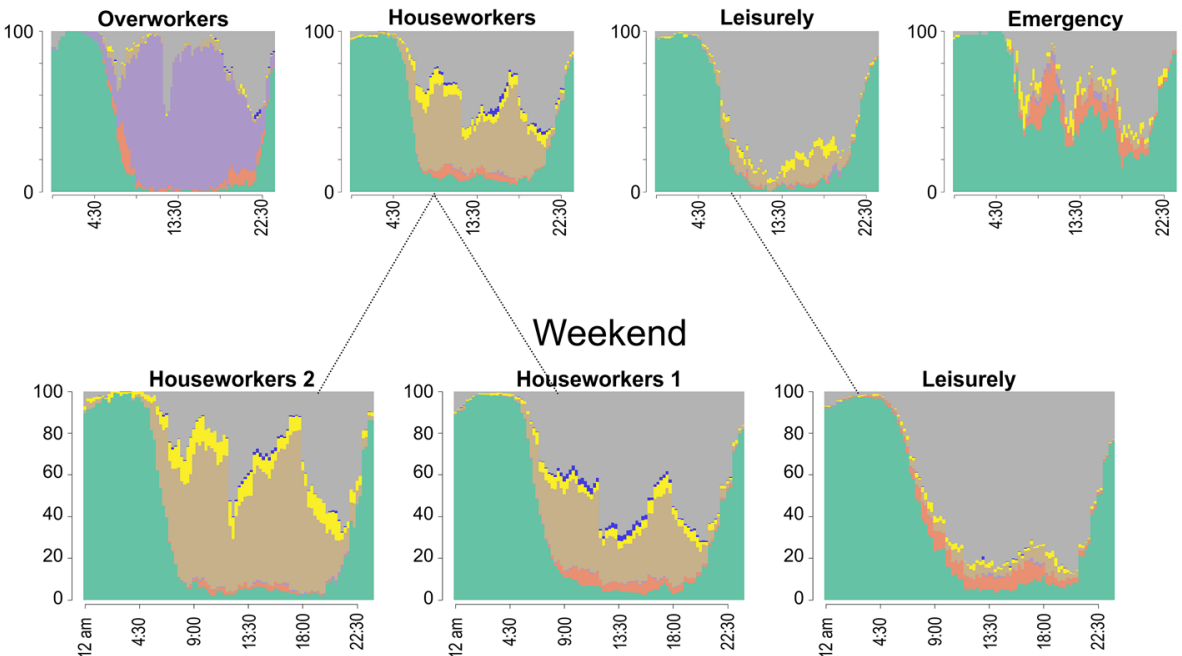

Fig. 2 Daily Patterns on Weekdays and Weekends 
spent on doing housework, as well as some adult care and childcare. As was discussed above, Group 4 (weekends) reports more childcare instances than Group 5 (weekends). Thus, for both Group 1 on weekdays and Group 4 ('Houseworkers 1') on weekends, childcare responsibilities stretch out throughout the day, whereas for Group 5 ('Houseworkers 2'), most instances of childcare take place in the afternoons. However, the latter group spends a longer time on adult care than the 'Houseworkers 1' group (see Tables 1 and 2). Additionally, in Fig. 2, Groups 3 on weekdays and weekends spend most of the day on leisure activities. The only difference between the two 'Leisurely Carers' is that this category of caregivers spends a longer time on travel on weekends than on weekdays, suggesting travel related to leisure activities.

To show the proportional sizes of the different categories of caregivers, Fig. 3 summarizes the proportional (to the samples) sizes of the groups identified by the cluster analysis. It shows that the largest group among caregivers is the 'Houseworkers' category. Most family caregivers fall into this category. On weekdays, the next largest category is 'Full-time Workers'. On weekends, both 'Full-time Workers' and 'Leisurely Carers' represent a considerable percentage of caregivers. 'Part-time Workers', 'Overworkers', 'Intensive Carers', and those who needed medical attention ('Emergency Diaries') represent comparatively smaller proportions of all family caregivers.

\section{Multinomial Regression of the Caregiver Cluster Membership}

The primary dependent variable used for the multinomial regression analysis is the categories of at-home eldercare-providers identified from the cluster analysis of sequences by the optimal matching technique described in the section above.

The multinomial logistic regression models include a number of factors relating to the demographic profiles of caregiver categories. These models are run separately for clusters of weekday and weekend diaries. We use the 'Houseworkers' category on weekdays and 'Part-time Workers' on weekends as the referent. In the model outputs,

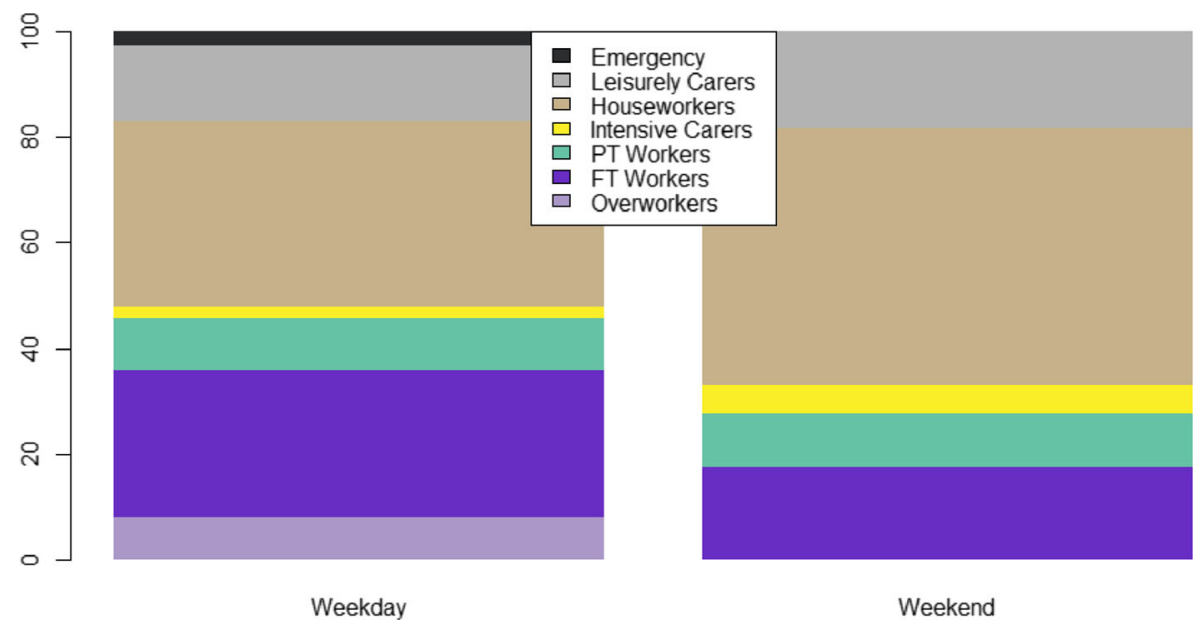

Fig. 3 Percentage by Cluster 
we report average marginal effects to avoid confusion with reference groups and facilitate results' interpretation.

We control for employment status, household income, education, the number of children under 15 in the household, the number of women in the household, respondents' gender, homeownership, and marital status.

Tables 3 and 4 summarize the results of the average marginal effects from the multinomial logistic regression models for weekdays (Table 3) and weekends (Table 4). The dependent variables for both models are family caregivers' categories identified in the cluster analysis, seven for the weekday diaries and six for the weekend diaries.

Multinomial models indicate that employed caregivers are more likely than nonemployed to belong to one of the three groups of workers ('Overworkers', 'Full-time Workers', and 'Part-time Workers'). The reverse is true among all other types of caregivers.

Employed caregivers are significantly more likely to be in the 'Overworkers' group than non-employed. Caregivers in the second quartile of household income are statistically more likely to be in this group than those in the lowest quartile. Caregivers over 65 years of age are statistically significantly linked to a lower likelihood of belonging to this group than those under 65. Caregivers with more children are significantly more likely to be in this group than those with fewer children, and women have a significantly lower likelihood to belong to this group than men.

Both on weekdays and weekends, women are statistically significantly less likely to belong to 'Full-time Workers' than men. This is an interesting finding that men in Japan are more likely to belong to the group, including the proverbial 'second shifters' than women when it comes to eldercare provision to their parents or parents-in-law. It is also explained by the labor force structure in Japan, where lower proportions of women land full-time jobs, and men are compelled to continue working even if they have to take care of their elderly parents. The higher quartiles of household income are significantly linked to a higher likelihood of belonging to the 'Full-time Workers' group among weekday diaries, but the same is not true in weekend diaries. This finding indicates that regular employment in Japan is more normative and brings a steadier and higher income for families. However, the education level higher than high school is surprisingly statistically less likely to indicate this group's belonging than to have education up to middle school.

As to 'Part-time Workers', being married is significantly less likely to indicate the belonging to this group in weekday diaries. Thus, the associations show that this pattern is more common among those who are not married than among those who are. In weekend diaries, caregivers with lower education levels are significantly more likely to display time-use patterns of 'Part-time Workers'.

Caregivers in the lowest quartile of household income both on weekdays (Table 3) and weekends (Table 4) have a statistically more significant likelihood to belong to the 'Houseworkers' group, in particular those with higher childcare responsibilities (sandwich caregivers). Additionally, women caregivers are statistically more likely to belong to 'Houseworkers' than men caregivers. Married caregivers are also statistically more likely to belong to 'Houseworkers' than non-married caregivers. Thus, the results suggest that married Japanese women-caregivers are more likely to have daily patterns 


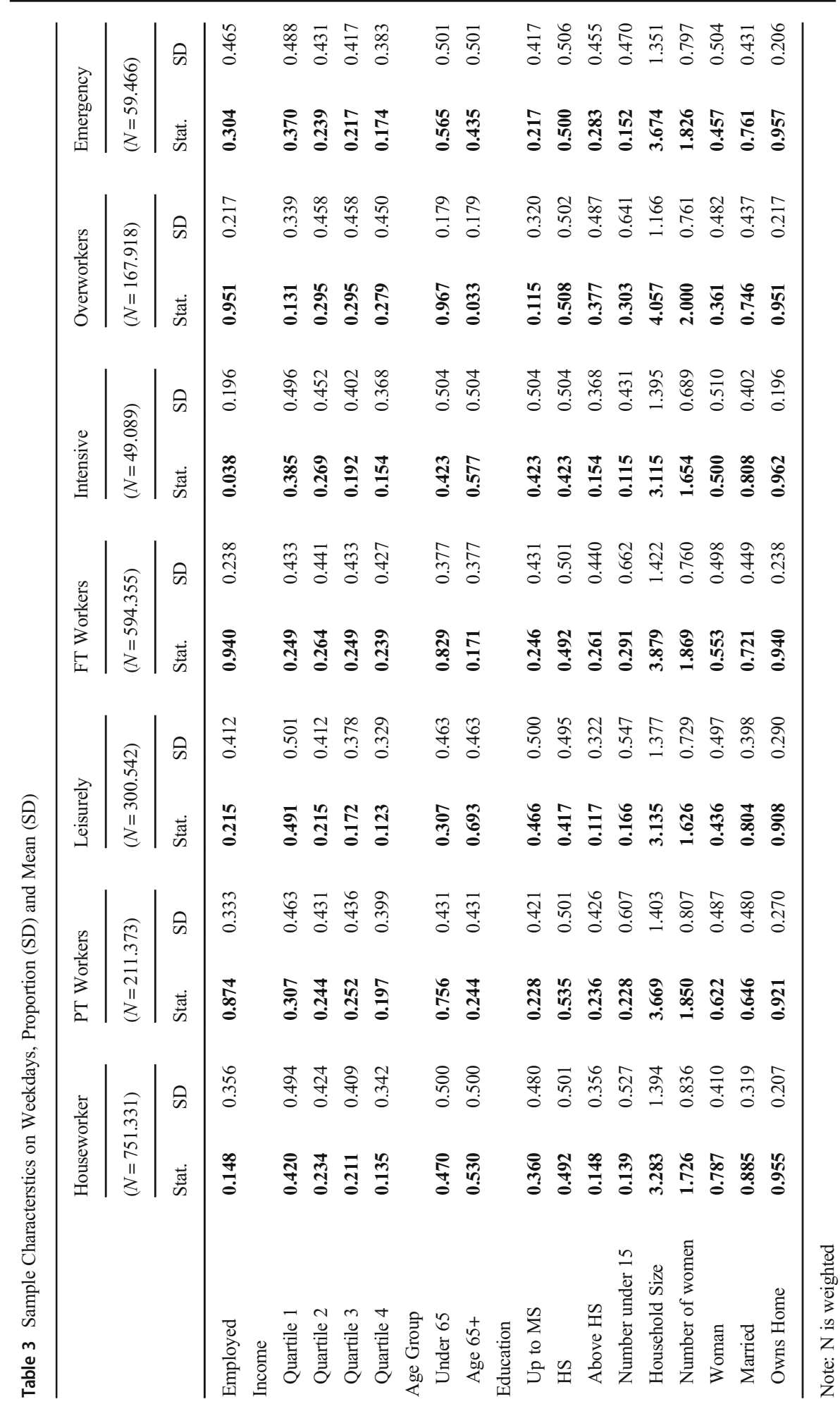




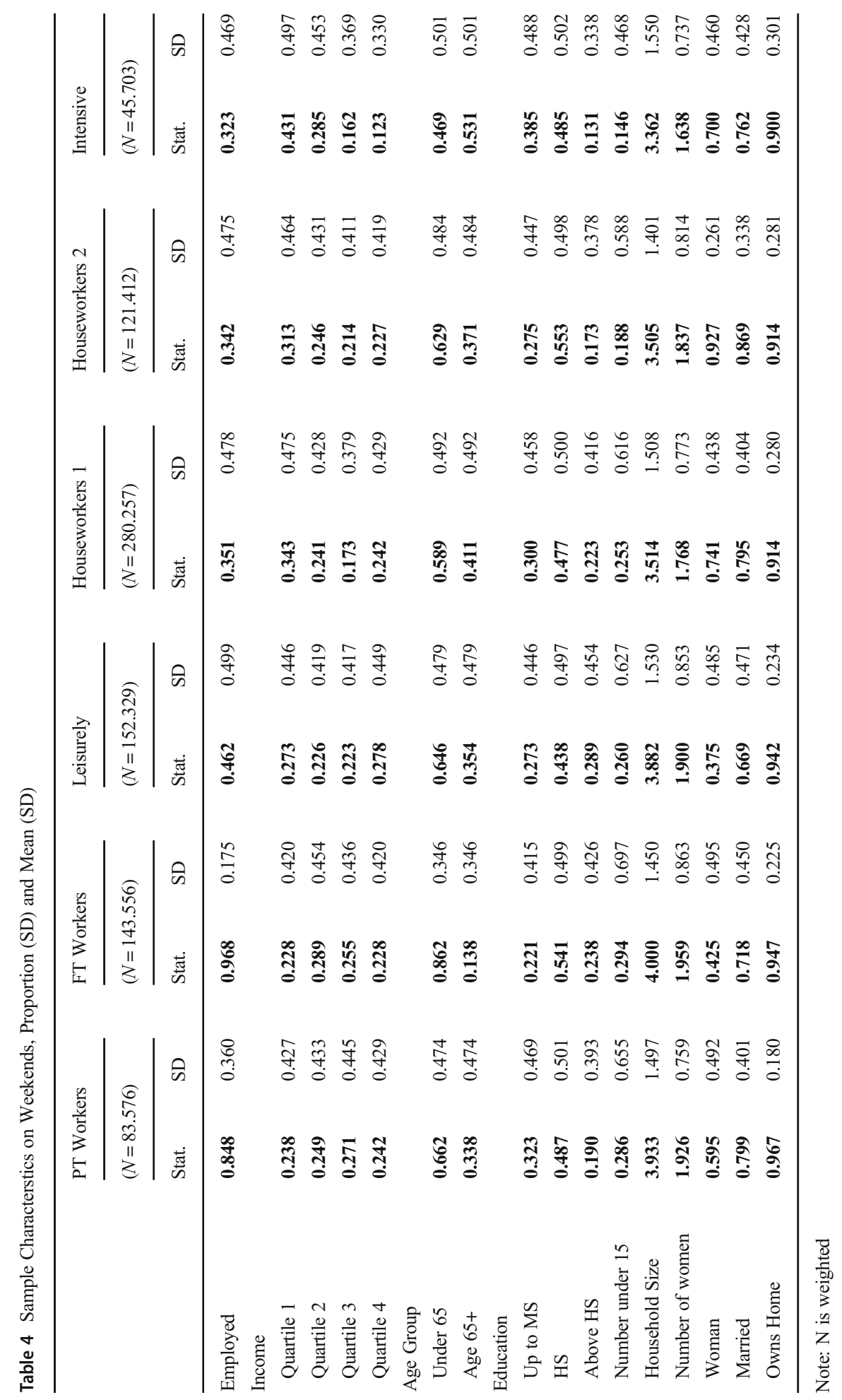


of 'Houseworkers'. Moreover, considering that this type of family caregivers is the largest, it represents a larger fraction of caregivers' daily routines (see Fig. 3).

In weekday diaries, caregivers of 65 and above are significantly more likely to belong to 'Leisurely Caregivers'. The same is not true for weekend diaries. Thus, it appears that the retired elderly are more likely to represent the daily patterns for the weekday 'Leisurely Caregivers' than those still in the workforce. In weekend diaries, women and married caregivers are less likely to be 'Leisurely Caregivers' than men and

Table 5 Average marginal effects from the multinomial logistic regression model of cluster belonging on weekdays

\begin{tabular}{|c|c|c|c|c|c|c|c|}
\hline & Houseworkers & $\begin{array}{r}\text { P T } \\
\text { Workers }\end{array}$ & Leisurely & $\begin{array}{r}\text { F T } \\
\text { Workers }\end{array}$ & Intensive & Overworkers & Emergency \\
\hline Employed & $\begin{array}{c}-0.590^{* * *} \\
(0.034)\end{array}$ & $\begin{array}{l}0.197^{* * * *} \\
(0.027)\end{array}$ & $\begin{array}{c}-0.125^{* * *} \\
(0.026)\end{array}$ & $\begin{array}{l}0.516^{* * *} \\
(0.036)\end{array}$ & $\begin{array}{c}-0.048^{* * * *} \\
(0.012)\end{array}$ & $\begin{array}{l}0.090^{\text {**** }} \\
(0.025)\end{array}$ & $\begin{array}{c}-0.040^{* * * *} \\
(0.010)\end{array}$ \\
\hline \multicolumn{8}{|l|}{ Income } \\
\hline Quartile 1 & Ref. & Ref. & Ref. & Ref. & Ref. & Ref. & Ref. \\
\hline Quartile 2 & $\begin{array}{c}-0.200^{* *} \\
(0.068)\end{array}$ & $\begin{array}{c}0.044 \\
(0.035)\end{array}$ & $\begin{array}{l}-0.019 \\
(0.047)\end{array}$ & $\begin{array}{c}0.142 \\
(0.073)\end{array}$ & $\begin{array}{c}0.006 \\
(0.014)\end{array}$ & $\begin{array}{l}0.029^{*} \\
(0.014)\end{array}$ & $\begin{array}{l}-0.003 \\
(0.019)\end{array}$ \\
\hline Quartile 3 & $\begin{array}{l}-0.132 \\
(0.070)\end{array}$ & $\begin{array}{c}0.012 \\
(0.031)\end{array}$ & $\begin{array}{c}0.003 \\
(0.049)\end{array}$ & $\begin{array}{l}0.127^{*} \\
(0.058)\end{array}$ & $\begin{array}{l}-0.006 \\
(0.010)\end{array}$ & $\begin{array}{c}0.017 \\
(0.013)\end{array}$ & $\begin{array}{l}-0.021 \\
(0.016)\end{array}$ \\
\hline Quartile 4 & $\begin{array}{c}-0.248^{* * *} \\
(0.072)\end{array}$ & $\begin{array}{c}0.078 \\
(0.046)\end{array}$ & $\begin{array}{l}-0.035 \\
(0.051)\end{array}$ & $\begin{array}{l}0.217^{* *} \\
(0.070)\end{array}$ & $\begin{array}{l}-0.009 \\
(0.007)\end{array}$ & $\begin{array}{c}0.016 \\
(0.010)\end{array}$ & $\begin{array}{l}-0.019 \\
(0.016)\end{array}$ \\
\hline \multicolumn{8}{|l|}{ Age } \\
\hline Age $65+$ & $\begin{array}{l}-0.020 \\
(0.071)\end{array}$ & $\begin{array}{l}-0.034 \\
(0.032)\end{array}$ & $\begin{array}{l}0.284^{* * *} \\
(0.052)\end{array}$ & $\begin{array}{c}-0.184^{* * * *} \\
(0.051)\end{array}$ & $\begin{array}{l}-0.006 \\
(0.008)\end{array}$ & $\begin{array}{c}-0.039^{* *} \\
(0.014)\end{array}$ & $\begin{array}{l}-0.001 \\
(0.012)\end{array}$ \\
\hline \multicolumn{8}{|l|}{ Education } \\
\hline Up to MS & Ref. & Ref. & Ref. & Ref. & Ref. & Ref. & Ref. \\
\hline HS & $\begin{array}{c}0.067 \\
(0.072)\end{array}$ & $\begin{array}{l}-0.026 \\
(0.037)\end{array}$ & $\begin{array}{c}0.021 \\
(0.038)\end{array}$ & $\begin{array}{l}-0.079 \\
(0.066)\end{array}$ & $\begin{array}{l}-0.005 \\
(0.007)\end{array}$ & $\begin{array}{c}0.015 \\
(0.011)\end{array}$ & $\begin{array}{c}0.008 \\
(0.011)\end{array}$ \\
\hline Above HS & $\begin{array}{c}0.140 \\
(0.093)\end{array}$ & $\begin{array}{l}-0.060 \\
(0.039)\end{array}$ & $\begin{array}{c}0.014 \\
(0.053)\end{array}$ & $\begin{array}{l}-0.165^{*} \\
(0.071)\end{array}$ & $\begin{array}{c}0.013 \\
(0.021)\end{array}$ & $\begin{array}{c}0.003 \\
(0.010)\end{array}$ & $\begin{array}{l}0.055^{*} \\
(0.022)\end{array}$ \\
\hline $\begin{array}{l}\text { \# of } \\
\text { children }\end{array}$ & $\begin{array}{l}-0.085 \\
(0.044)\end{array}$ & $\begin{array}{c}0.026 \\
(0.022)\end{array}$ & $\begin{array}{l}-0.072 \\
(0.037)\end{array}$ & $\begin{array}{l}0.130^{* * * *} \\
(0.035)\end{array}$ & $\begin{array}{l}-0.008 \\
(0.004)\end{array}$ & $\begin{array}{l}0.020^{*} \\
(0.009)\end{array}$ & $\begin{array}{l}-0.011 \\
(0.013)\end{array}$ \\
\hline Woman & $\begin{array}{l}0.355^{\text {**** }} \\
(0.047)\end{array}$ & $\begin{array}{l}-0.023 \\
(0.028)\end{array}$ & $\begin{array}{c}-0.113^{* *} \\
(0.043)\end{array}$ & $\begin{array}{c}-0.136^{* *} \\
(0.051)\end{array}$ & $\begin{array}{l}-0.002 \\
(0.008)\end{array}$ & $\begin{array}{c}-0.046^{* *} \\
(0.018)\end{array}$ & $\begin{array}{l}-0.034^{*} \\
(0.014)\end{array}$ \\
\hline Married & $\begin{array}{c}0.345^{* * *} \\
(0.060)\end{array}$ & $\begin{array}{c}-0.113^{*} \\
(0.045)\end{array}$ & $\begin{array}{l}-0.069 \\
(0.063)\end{array}$ & $\begin{array}{c}-0.159^{*} \\
(0.068)\end{array}$ & $\begin{array}{c}0.009 \\
(0.010)\end{array}$ & $\begin{array}{l}-0.016 \\
(0.012)\end{array}$ & $\begin{array}{c}0.002 \\
(0.013)\end{array}$ \\
\hline $\begin{array}{l}\text { Owns } \\
\text { Home }\end{array}$ & $\begin{array}{c}0.138 \\
(0.084)\end{array}$ & $\begin{array}{l}-0.014 \\
(0.047)\end{array}$ & $\begin{array}{l}-0.095 \\
(0.080)\end{array}$ & $\begin{array}{l}-0.065 \\
(0.079)\end{array}$ & $\begin{array}{c}0.010 \\
(0.008)\end{array}$ & $\begin{array}{c}0.001 \\
(0.016)\end{array}$ & $\begin{array}{l}0.026^{*} \\
(0.013)\end{array}$ \\
\hline \# of women & $\begin{array}{c}0.030 \\
(0.039)\end{array}$ & $\begin{array}{l}-0.021 \\
(0.018)\end{array}$ & $\begin{array}{c}0.038 \\
(0.024)\end{array}$ & $\begin{array}{l}-0.061 \\
(0.039)\end{array}$ & $\begin{array}{c}0.002 \\
(0.004)\end{array}$ & $\begin{array}{c}0.002 \\
(0.005)\end{array}$ & $\begin{array}{c}0.010 \\
(0.007)\end{array}$ \\
\hline Weighted N & 751.331 & 211.373 & 300.542 & 594.355 & 49.089 & 167.918 & 59.466 \\
\hline
\end{tabular}

Standard errors in parentheses. ${ }^{*} p<0.05,{ }^{* *} p<0.01,{ }^{* * *} p<0.001$. MS = 'Middle School'; HS = 'High School' 
Table 6 Average marginal effects from the multinomial logistic regression model of cluster belonging on weekends

\begin{tabular}{|c|c|c|c|c|c|c|}
\hline & PT Workers & FT Workers & Leisurely & Houseworkers 1 & Houseworkers 2 & Intensive \\
\hline Employed & $0.170^{* * * *}$ & $0.306^{* * * *}$ & $-0.094^{* * *}$ & $-0.269^{* * *}$ & $-0.072^{* * *}$ & $-0.041^{* *}$ \\
\hline & $(0.019)$ & $(0.023)$ & $(0.025)$ & $(0.032)$ & $(0.019)$ & $(0.016)$ \\
\hline \multicolumn{7}{|l|}{ Income } \\
\hline Quartile 1 & Ref. & Ref. & Ref. & Ref. & Ref. & Ref. \\
\hline \multirow[t]{2}{*}{ Quartile 2} & 0.015 & 0.011 & 0.039 & -0.073 & -0.020 & 0.028 \\
\hline & $(0.021)$ & $(0.015)$ & $(0.037)$ & $(0.043)$ & $(0.024)$ & $(0.021)$ \\
\hline \multirow[t]{2}{*}{ Quartile 3} & $0.063^{*}$ & 0.036 & 0.040 & $-0.160^{* * * *}$ & 0.019 & 0.002 \\
\hline & $(0.025)$ & $(0.019)$ & $(0.039)$ & $(0.045)$ & $(0.032)$ & $(0.018)$ \\
\hline \multirow[t]{2}{*}{ Quartile 4} & 0.009 & -0.001 & 0.019 & -0.011 & -0.009 & -0.007 \\
\hline & $(0.026)$ & $(0.017)$ & $(0.040)$ & $(0.050)$ & $(0.027)$ & $(0.020)$ \\
\hline \multicolumn{7}{|l|}{ Age } \\
\hline \multirow[t]{2}{*}{ Age $65+$} & 0.028 & $-0.032^{*}$ & 0.000 & 0.005 & -0.018 & 0.017 \\
\hline & $(0.022)$ & $(0.015)$ & $(0.031)$ & $(0.038)$ & $(0.022)$ & $(0.020)$ \\
\hline \multicolumn{7}{|l|}{ Education } \\
\hline Up to MS & Ref. & Ref. & Ref. & Ref. & Ref. & Ref. \\
\hline \multirow[t]{2}{*}{ HS } & $-0.063^{*}$ & -0.030 & -0.018 & 0.077 & 0.037 & -0.003 \\
\hline & $(0.025)$ & $(0.016)$ & $(0.031)$ & $(0.040)$ & $(0.021)$ & $(0.017)$ \\
\hline \multirow[t]{2}{*}{ Above HS } & $-0.096^{* * *}$ & $-0.043^{*}$ & 0.075 & 0.078 & -0.001 & -0.014 \\
\hline & $(0.026)$ & $(0.018)$ & $(0.039)$ & $(0.048)$ & $(0.024)$ & $(0.024)$ \\
\hline \multirow[t]{2}{*}{ \# of children } & 0.014 & 0.013 & -0.000 & 0.022 & -0.032 & -0.017 \\
\hline & $(0.012)$ & $(0.007)$ & $(0.020)$ & $(0.025)$ & $(0.018)$ & $(0.015)$ \\
\hline \multirow[t]{2}{*}{ Woman } & -0.004 & $-0.061^{* * *}$ & $-0.327^{* * *}$ & $0.168^{* * *}$ & $0.210^{* * * *}$ & 0.014 \\
\hline & $(0.015)$ & $(0.015)$ & $(0.031)$ & $(0.032)$ & $(0.019)$ & $(0.013)$ \\
\hline \multirow[t]{2}{*}{ Married } & 0.022 & -0.021 & $-0.128^{* * *}$ & 0.074 & $0.083^{* * *}$ & -0.030 \\
\hline & $(0.020)$ & $(0.016)$ & $(0.038)$ & $(0.042)$ & $(0.021)$ & $(0.023)$ \\
\hline \multirow[t]{2}{*}{ Owns Home } & 0.031 & -0.000 & 0.059 & -0.064 & -0.014 & -0.012 \\
\hline & $(0.037)$ & $(0.026)$ & $(0.047)$ & $(0.065)$ & $(0.035)$ & $(0.025)$ \\
\hline \multirow[t]{2}{*}{ \# of women } & -0.004 & 0.006 & $0.053^{* *}$ & -0.032 & -0.007 & -0.016 \\
\hline & $(0.010)$ & $(0.007)$ & $(0.017)$ & $(0.021)$ & $(0.013)$ & $(0.011)$ \\
\hline Weighted $N$ & 83.576 & 143.556 & 152.329 & 280.257 & 121.412 & 45.703 \\
\hline
\end{tabular}

Standard errors in parentheses. ${ }^{*} p<0.05,{ }^{* *} p<0.01,{ }^{* * *} p<0.001 . . \mathrm{MS}=$ 'Middle School'; HS = 'High School'

non-married people. Furthermore, caregivers living in households with more coresiding adult women are more likely to belong to this group, perhaps because this type of household structure allows large amounts of leisure activities to be undertaken by the caregivers due to social gender roles expectations.

No particular demographic stands out significantly with the likelihood to belong to the 'Intensive Caregivers', which might indicate that the need for intensive adult care for the elderly may arise regardless of the demographic factors tested in our models. 
The only significant factor is that non-employed caregivers are more likely to be 'Intensive Carers' than employed. This indicates that as soon as the caregiving burden increases, the employment is rarely maintained, even in Japan, with its progressive eldercare policies (Tables 5 and 6).

Non-employed caregivers with higher levels of education, men, and homeowners are statistically more likely to be among those who needed medical attention on the diary day ('Emergency Diaries') than employed, lower educated, women, and those who live in rented housing.

\section{Discussions and Conclusions}

Considering that Japan is a super-ageing society, the present research provides a glimpse into how elder caregivers in such societies spend their days and what activities they involve in more. Overall, our results show that the caregiver categories form around paid work time, housework, and leisure times, as the previous research on overall daily patterns suggests (Flood et al. 2018; Glorieux et al. 2010).

The caregivers, whose daily activities are dominated by housework ('Houseworkers'), comprise the largest share of Japanese elder caregivers. They spend twice as much time on housework, eldercare, and childcare than the average for caregivers, mostly represented by women, and more likely to be out of employment. This indicates a dire need for support of family caregivers, particularly women, to continue to work if the gender inequality in family caregiving needs to be closed.

On weekdays, about $46 \%$ of all caregivers fall into the 'Workers' categories. Categories of working caregivers form around the time commitments to paid work: 1) 'Overworkers' ( $>8 \mathrm{~h}$ of paid work, $11 \mathrm{~h}$ a day, on average), 2) 'Full-time Workers' (about $8 \mathrm{~h}$ a day), and 3) 'Part-time Workers' (about $4.5 \mathrm{~h}$ daily, on average). Depending on how much time the workers spend on paid work activities, their caregiving time and schedule vary. The most care is provided by the 'Part-time Workers' and the least-by the 'Overworkers'.

Interestingly, 'Full-time Worker' caregivers, who are usually portrayed in the western literature as mostly women (Hochschild and Machung 1989), in the context of eldercare in Japan, are more likely to be men than women. This category of caregivers provides help during times outside of their work hours. Thus, the amount of total work, paid and unpaid, performed by these caregivers must exact a high burden on their mental and physical health. The policy intervention should include tools to help family caregivers who work full-time.

The cluster analysis also helped to identify intensive caregivers. This category of caregivers provides almost $9.5 \mathrm{~h}$ of eldercare daily, which is a longer commitment than a full-time job. Although only $2.3 \%$ on weekdays and $5.5 \%$ of weekends were categorized as intensive caregivers, these numbers are to increase simultaneously with the elderly population in Japan, and early strategies on how to support them need to be developed on the policy level.

Our study is one of the first to address the daily lifestyles, as well as similarities and differences between elder caregivers on weekdays and weekends. The findings highlight the gender inequality in family caregiving and its manifestations because the largest category of caregivers, 'Houseworkers', is still represented mostly by women. 
Conversely, 'Full-time Workers' taking care of the elderly, are more likely to be men than women. Similarly, 'Intensive Carers' are as likely to be men as they are to be women.

One limitation of the present research is that asking the respondents a direct question about their caregiving responsibilities translate very little in how much time they actually spend on caregiving and satellite unpaid work. For instance, although the 'Overworkers' and 'Leisurely Caregivers' categories identify themselves as elder caregivers, their actual time commitments to providing care and related activities are low. The average time that all caregivers spend on care activities and unpaid work would, therefore, overestimate a lot for some categories of caregivers and underestimate for others.

Another limitation is that in this exploratory study, we restricted our sample only to self-reported elder caregivers. A lot could be revealed when the common patterns of noncaregivers are compared to the patterns of caregivers presented in this study. Some, without doubt, will be very similar, and some will be revealingly different. Future research can explore this direction to establish unique patterns and activity timings for caregivers.

An additional limitation is that the present study uses a little dated data. There are certain difficulties in employing the later waves of STULA. Anonymized microfiles for the later cycles of STULA, for example, 2011 and 2016, are not available at the moment. Therefore, the analyses can only be performed on raw data at the data centers in Japan. However, two reasons prevented us from using a newer version. First, the 2020 pandemic restricted travel, including to Japan. Second, receiving the releases of the data analyzed at the data centers takes a considerably long time, in our own experience, up to half a year and often more. This would be impossible to do under current conditions (no peer-review process deadline would be met). Together with other scholars, we are lobbying with the Japanese Bureau of Statistics to precipitate the process in the future. We, however, think that the results presented in this paper on categories of caregivers would not be very different for the period between 2006 and 2017. ${ }^{4}$ The limitation of using the 2006 data, however, not likely to affect the categories of the main caregivers as established in the present manuscript.

Future research could also focus on elder caregivers in other countries and in other welfare regimes to explore the consequences of eldercare on gender and economic equality.

Acknowledgements Authors thank Dr. Sara Zella and two anonymous reviewers for their valuable comments.

Availability of Data and Material The data is used upon the agreement with the Japanese Bureau of Statistics.

Authors' Contributions the theoretical framing, statistical analysis, and drafting of the paper is provided by the lead author (Kolpashnikova). The second author was responsible for the acquisition of data and critical revision of the draft. All authors read and approved the final manuscript. The preprint of this work is available on SocArxiv: https://doi.org/10.31235/osf.io/7rbg5

Funding This project has received funding from the European Union's Horizon 2020 research and innovation programme under the Marie Sklodowska-Curie grant agreement No 892101 (awardee: Kamila

\footnotetext{
${ }^{4}$ In 2017, a new amendment to Family Leave Care law was introduced, which might have eased the working flexibility for people who have to provide eldercare.
} 
Kolpashnikova). This project has received funding from the European Research Council (ERC) under the European Union's Horizon 2020 research and innovation programme (awardee: Man Yee Kan; award 771736).

\section{Compliance with Ethical Standards}

Conflicts of Interest/Competing Interests Authors declare that there are no conflicts of interest to report with regard to the findings of the present paper.

Code Availability The data codes in $\mathrm{R}$ will be provided upon request.

Open Access This article is licensed under a Creative Commons Attribution 4.0 International License, which permits use, sharing, adaptation, distribution and reproduction in any medium or format, as long as you give appropriate credit to the original author(s) and the source, provide a link to the Creative Commons licence, and indicate if changes were made. The images or other third party material in this article are included in the article's Creative Commons licence, unless indicated otherwise in a credit line to the material. If material is not included in the article's Creative Commons licence and your intended use is not permitted by statutory regulation or exceeds the permitted use, you will need to obtain permission directly from the copyright holder. To view a copy of this licence, visit http://creativecommons.org/licenses/by/4.0/.

\section{References}

Abbott, A. (1995). Sequence analysis: New methods for old ideas. Annual Review of Sociology, 21(1), 93113.

Abbott, A., \& Tsay, A. (2000). Sequence analysis and optimal matching methods in sociology: Review and prospect. Sociological Methods \& Research, 29(1), 3-33.

Aoun, S., Deas, K., Toye, C., Ewing, G., Grande, G., \& Stajduhar, K. (2015). Supporting family caregivers to identify their own needs in end-of-life care: Qualitative findings from a stepped wedge cluster trial. Palliative Medicine, 29(6), 508-517.

Ato, M., \& Tsuya, N. (2018). Aspects of childless and aging society. In N. Tsuya, M. Ato, H. Nishioka, \& N. Fukuda (Eds.), Women and family in the age of low birthrate and aging society (pp. 1-55). Tokyo: Keio University Press.

Bianchi, S. M., Milkie, M. A., Sayer, L. C., \& Robinson, J. P. (2000). Is anyone doing the housework? Trends in the gender division of household. Social Forces, 79, 191-228.

Bianchi, S. M., Robinson, J. P., \& Milkie, M. A. (2006). Changing rhythms of American family life. New York, NY: Russell Sage Foundation.

Bittman, M., Fisher, K., Hill, P., \& Thomson, C. (2005). The time cost of care. International Journal of Time Use Research, 2(1), 54-66.

Boltz, M., Chippendale, T., Resnick, B., \& Galvin, J. E. (2015). Anxiety in family caregivers of hospitalized persons with dementia: Contributing factors and responses. Alzheimer Disease and Associated Disorders, 29(3), 236-241.

Bookman, A., \& Kimbrel, D. (2011). Families and elder care in the twenty-first century. The Future of Children, 21(2), 117-140.

Flood, S. M., Hill, R., \& Genadek, K. R. (2018). Daily temporal pathways: A latent class approach to time diary data. Social Indicators Research, 135(1), 117-142.

Folbre, N. (2012). For love and money: Care provision in the United States. New York: Russell Sage Foundation.

Freedman, V. A., Cornman, J. C., Carr, D., \& Lucas, R. E. (2019). Time use and experienced well-being of older caregivers: A sequence analysis. The Gerontologist, 59(5), e441-e450.

Fukuda, N. (2018). Characteristics and defining factors of parent-child support relationships: Focusing on the Sandwich generation. In N. Tsuya, M. Ato, H. Nishioka, \& N. Fukuda (Eds.), Women and family in the age of low birthrate and aging society (pp. 237-259). Tokyo: Keio University Press.

Gabadinho, A., Ritschard, G., Mueller, N. S., \& Studer, M. (2011). Analyzing and visualizing state sequences in R with TraMineR. Journal of Statistical Software, 40(4), 1-37. 
Glorieux, I., Laurijssen, I., Minnen, J., \& van Tienoven, T. P. (2010). In search of the harried leisure class in contemporary society: Time-use surveys and patterns of leisure time consumption. Journal of Consumer Policy, 33(2), 163-181.

Grapsa, E., \& Posel, D. (2016). Sequencing the real time of the elderly: Evidence from South Africa. Demographic Research, 35, 711-744.

Grigoryeva, A. (2017). Own gender, sibling's gender, parent's gender: The division of elderly parent care among adult children. American Sociological Review, 82(1), 116-146.

HelpAge International (2014). Global AgeWatch Index 2015. http:/www.helpage.org/global-agewatch/ population-ageing-data/global-rankings-table/. Accessed 25 Aug 2020.

Henretta, J. C., Grundy, E., \& Harris, S. (2001). Socioeconomic differences in having living parents and children: A US-British comparison of middle-aged women. Journal of Marriage and Family, 63(3), 852867.

Henz, U. (2010). Parent care as unpaid family labor: How do spouses share? Journal of Marriage and Family, $72(1), 148-164$

Hiroyama, R. 平. (2017). 息子介護に見るケア経験のジェンダ 対称性 (特集 家族介護のいま). 家計経済研究(113), 30-39.

Hochschild, A., \& Machung, A. (1989). The second shift: Working families and the revolution at home. New York, NY: Avon Books.

Hook, J. L. (2017). Women's housework: New tests of time and money. Journal of Marriage and Family, 79(1), 179-198.

Hou, R. J., Wong, S. Y.-S., Yip, B. H.-K., Hung, A. T., Lo, H. H.-M., Chan, P. H., et al. (2014). The effects of mindfulness-based stress reduction program on the mental health of family caregivers: A randomized controlled trial. Psychotherapy and Psychosomatics, 83(1), 45-53.

Ikeda, S. (2017). Family care leave and job quitting due to caregiving: Focus on the need for long-term leave. Japan Labor Review, 14(1).

Inamori, K. (2017). Current situation and problems of legislation on long-term Care in Japan's super-aging society. Japan Labor Review, 14(1), 8-24.

Kikuzawa, S. 菊. (2007). 女性の介護: ライフコ ス 点からの考察. 福祉社会学研究, 2007(4), 99-119.

Kolpashnikova, K., \& Kan, M.-Y. (2020). Hebdomadal patterns of compensatory behaviour: Weekday and weekend housework participation in Canada, 1986-2010. Work, Employment and Society, 34(2), 174 192.

Moen, P., Robison, J., \& Fields, V. (1994). Women's work and caregiving roles: A life course approach. Journal of Gerontology, 49(4), S176-S186.

Morikawa, M. (2018). Development of "nursing care" within Japanese eldercare policy. In Y. Suda, K. Hiraoka, \& M. Morikawa (Eds.), East Asian eldercare (pp. 280-305). Tokyo: Toshindo.

Nichols, L. S., \& Junk, V. W. (1997). The sandwich generation: Dependency, proximity, and task assistance needs of parents. Journal of Family and Economic Issues, 18(3), 299-326.

Nishimoto, M. (2017). Choices of leave when caring for family members: What is the best system for balancing family care with employment? Japan Labor Review, 14(1), 45-67.

Patterson, S. E., \& Margolis, R. (2019). The demography of multigenerational caregiving: A critical aspect of the gendered life course. Socius, 5, 2378023119862737.

Ruppanner, L., \& Treas, J. (2015). Working weekends: Changing European time regimes and gender inequality in household labor. Journal of Family Issues, 36(13), 1782-1809.

Saito, M. (2017). Current issues regarding family caregiving and gender equality in Japan: Male caregivers and the interplay between caregiving and masculinities. Japan Labor Review, 14(1).

Sankoff, D., \& Kruskal, J. B. (1983). Time warps, string edits, and macromolecules: The theory and practice of sequence comparison. Reading, MA: Addison-Wesley.

Schulz, R., \& Eden, J. (2016). Families caring for an aging America. Washington, DC: National Academies Press.

Silverstein, M., \& Giarrusso, R. (2010). Aging and family life: A decade review. Journal of Marriage and Family, 72(5), 1039-1058.

Statistics Bureau. (2016). Survey on time use and leisure activities. Japan: Tokyo.

Studer, M., \& Ritschard, G. (2016). What matters in differences between life trajectories: A comparative review of sequence dissimilarity measures. Journal of the Royal Statistical Society. A, 179(2), 481-511.

Suh, J. (2016). Measuring the "sandwich": Care for children and adults in the American time use survey 2003-2012. Journal of Family and Economic Issues, 37(2), 197-211.

Szinovacz, M. E., \& Davey, A. (2008). The division of parent care between spouses. Ageing \& Society, 28(4), $571-597$. 
Tamiya, Y., \& Shikata, M. (2010). Analysis of time use surveys on work and care in Japan. In D. Budlender (Ed.), Time use studies and unpaid care work (pp. 164-192). New York: Routledge.

Tay, K. C. P., Seow, C. C. D., Xiao, C., Lee, H. M. J., Chiu, H. F., \& Chan, S. W.-C. (2016). Structured interviews examining the burden, coping, self-efficacy, and quality of life among family caregivers of persons with dementia in Singapore. Dementia, 15(2), 204-220.

Tsudome, M. 津. (2018). 男性の介護労働: 男性介護者の介護実態と支援課題 (特集 男性労働). 日本労働研究雑誌, $60(10), 40-51$.

Weisser, F. B., Bristowe, K., \& Jackson, D. (2015). Experiences of burden, needs, rewards and resilience in family caregivers of people living with motor neurone disease/amyotrophic lateral sclerosis: A secondary thematic analysis of qualitative interviews. Palliative Medicine, 29(8), 737-745.

Wolf, D. A., \& Soldo, B, J. (1994). Married women's allocation of time to employment and care of elderly parents. Journal of Human resources, 29(4), 1259-1276.

Yajima, Y. (2017). Frameworks for balancing work and long-term care duties, and support needed from enterprises. Japan Labor Review, 14(1).

Yamashita, J., \& Soma, N. (2015). The double responsibilities of care in Japan: Emerging new social risks for women providing both childcare and care for the elderly. In R. K. H. Chan, J. Zinn, \& L. Wang (Eds.), New Life Courses, Social Risks and Social Policy in East Asia (pp. 113-129). London: Routledge.

Zuba, M., \& Schneider, U. (2013). What helps working informal caregivers? The role of workplace characteristics in balancing work and adult-care responsibilities. Journal of Family and Economic Issues, 34(4), 460-469.

Publisher's Note Springer Nature remains neutral with regard to jurisdictional claims in published maps and institutional affiliations. 